Rza-zadeh Nuray Rauf, Azerbaijan University of Tourism and Management, Baku, Republic of Azerbaijan, e-mail: nurayka_91@mail.ru

\title{
STUDY OF THE ECONOMIC POTENTIAL OF THE INNOVATIVE DEVELOPMENT OF HOTEL ENTERPRISES IN AZERBAIJAN
}

Introduction. Today's hotel industry is an increasingly competitive industry in the hospitality market.

In modern circumstances, we agree that achieving a competitive advantage in the hotel business is mainly correlated with the implementation of advances in hotel business activities.

In the hotel business, creativity is the process of creating and introducing new methods of operation that differ from the standard ones, as well as developing innovative hotel goods, new ways of extending a hotel company's services, and creating conditions for guests to feel more relaxed.

The enterprise's ability to achieve a particular innovative target, i.e. the degree of the enterprise's readiness to execute the innovative change plan and the implementation of innovative technologies, goods, etc., is calculated as the enterprise's innovative potential [9].

The company's technological capacity forms a variety of structural components: intellectual, scientific, manufacturing and technical, economic, marketing, organizational and managerial.

At the intersection of all its structural components, the optimum use of a hotel enterprise's creative capacity is achieved. Therefore, they complement each other, creative capacity should be viewed not only from the viewpoint of a variable approach as a combination of resources, but also based on the principles of systematic method implementation.
One of the main features of this method is the synergy effect, i.e. an improvement in the performance of the entire creative potential process from the interaction of its components. The components of the company's creative capacity lead to the successful implementation of revolutionary practices and structural changes in the company's growth as they are tightly integrated and constantly communicating with each other.

Main part. Despite the fact that Azerbaijan's hotel business is still at the beginning of the road of development, domestic hotel companies should already make every effort to increase their technological capacity under conditions of high competition. The goal is to be able to provide and introduce consumers with innovative services in order to gain advantages over customers [3].

Choosing an innovative approach depends on the state of innovative ability and is therefore very critical for its objective assessment.

It is best to use Harrington's verbal-numerical scale for a qualitative assessment of the enterprise's level of creative capacity and the characteristics of its strengths in executing innovative activities. Here, the description of the results of quantitative calculations is given based on the classification of three grades of creative ability (high, medium and low) (Table 1). The values of the revolutionary potential integral indicator and its individual structural components are set within the range from 0 to 100 [7].

Table 1

Interpretation of innovative potential values

\begin{tabular}{|c|c|c|}
\hline Level of potential & Value range of innovation potential & $\begin{array}{c}\text { Qualitative characteristics of the state } \\
\text { of innovation potential }\end{array}$ \\
\hline 1 & 2 & 3 \\
\hline (High) $H$ & $\begin{array}{l}\mathrm{IP}=100 \\
80 \leq \mathrm{IP}<100\end{array}$ & $\begin{array}{l}\text { Corresponds to the best state of development of } \\
\text { innovative potential (IP). } \\
\text { Excellent condition of IP. The company has the } \\
\text { maximum opportunities for innovation and uses } \\
\text { them effectively. The company is at the level of } \\
\text { the world leader in its industry }\end{array}$ \\
\hline (Medium) $M$ & $\begin{array}{l}63 \leq \mathrm{IP}<80 \\
33<\mathrm{IP}<66 \\
\mathrm{IP}=33\end{array}$ & $\begin{array}{l}\text { Good state of innovation potential. The enter- } \\
\text { prise has significant opportunities for innovation } \\
\text { and uses them effectively. Corresponds to the } \\
\text { state of the national leader in its industry. }\end{array}$ \\
\hline
\end{tabular}


Ending of table 1

\begin{tabular}{|l|l|l|}
\hline 1 & \multicolumn{1}{|c|}{2} & \multicolumn{1}{|c|}{3} \\
\hline & & $\begin{array}{l}\text { Satisfactory condition of SP. The company has } \\
\text { the average capacity for innovation. Develop- } \\
\text { ment of IP and activation of its use is required. } \\
\text { The minimum acceptable level of innovation po- } \\
\text { tential. Conforms to the ultimate level of com- } \\
\text { petitiveness; urgent investments in the develop- } \\
\text { ment of components of innovative potential are } \\
\text { required }\end{array}$ \\
\hline Low $) L$ & $20 \leq \mathrm{IP}<33$ & $\begin{array}{l}\text { Poor state of innovation potential. Serious action } \\
\text { is required to change the enterprise development } \\
\text { strategy. } \\
\text { Lack of opportunities for innovation. The com- } \\
\text { pany may be classified as insolvent. }\end{array}$ \\
\hline
\end{tabular}

Source: Dorofeev V.D., Dresvyannikov V.A. (2003). Innovation Management: textbook. Penza, Publishing House of Penza State University. 189 p.

Based on an analysis of the activities of capital hotels, we conducted a study of the creative potential of hotel enterprises. They are the most preferred and visited visitors, according to the booking.com reservation system, the object of the visit is leisure, entertainment and relaxation. As noted above, the following 4-star hotels are included: Gorgud Hotel \& SPA, Askar Hotel, All Stars, Baku Winter Park Hotel, Demir Yol Plaza Hotel, Metro City Hotel, Baku City Hotel [10].

Competition is intensifying here today, and it seems important to determine what forces are operating on the segment and what opportunities are awaiting its current and future participants.
We consider it necessary to assess their innovative capabilities in order to determine the promising directions for the growth of these enterprises and to choose the optimal management strategies.

The values of quantitative indicators of the structural components of the innovative potentials of these enterprises were calculated by us, based on the data of their reporting.

Actual values and corresponding levels of development of individual structural components, as well as integrated indicators of innovative potentials of the studied hotel enterprises are presented in Table 2.

Actual values and related growth rates of individual structural components and their critical measures of the innovative ability of Baku City Hotels ' studied hotel enterprises.

\begin{tabular}{|c|c|c|c|c|c|c|c|}
\hline & $\begin{array}{c}\text { Metro City } \\
\text { Hotel }\end{array}$ & $\begin{array}{c}\text { Gorgud } \\
\text { Hotel \& SPA }\end{array}$ & All Stars & $\begin{array}{l}\text { Winter Park } \\
\text { Hotel Baku }\end{array}$ & $\begin{array}{l}\text { Askar } \\
\text { Hotel }\end{array}$ & $\begin{array}{c}\text { Baku City } \\
\text { Hotel }\end{array}$ & $\begin{array}{l}\text { Demir Yol } \\
\text { Plaza Hotel }\end{array}$ \\
\hline $\begin{array}{l}\text { Intellectual } \\
\text { component }\end{array}$ & $\begin{array}{c}36,6 \\
M\end{array}$ & $\begin{array}{c}36,8 \\
M\end{array}$ & $\begin{array}{c}36,2 \\
M\end{array}$ & $\begin{array}{c}34,0 \\
\mathrm{M}\end{array}$ & $\begin{array}{c}35,0 \\
M\end{array}$ & $\begin{array}{c}35,0 \\
M\end{array}$ & $\begin{array}{c}36,8 \\
M\end{array}$ \\
\hline $\begin{array}{l}\text { Research } \\
\text { component }\end{array}$ & $\begin{array}{l}0 \\
\mathrm{~L}\end{array}$ & $\begin{array}{l}0 \\
\mathrm{~L}\end{array}$ & $\begin{array}{l}0 \\
\mathrm{~L}\end{array}$ & $\begin{array}{l}0 \\
\mathrm{~L}\end{array}$ & $\begin{array}{l}0 \\
\mathrm{~L}\end{array}$ & $\begin{array}{l}0 \\
\mathrm{~L}\end{array}$ & $\begin{array}{l}0 \\
\mathrm{~L}\end{array}$ \\
\hline $\begin{array}{l}\text { Production and } \\
\text { technical compo- } \\
\text { nent }\end{array}$ & $\begin{array}{c}28,6 \\
M\end{array}$ & $\begin{array}{c}24,8 \\
M\end{array}$ & $\begin{array}{c}24,4 \\
M\end{array}$ & $\begin{array}{c}25,4 \\
M\end{array}$ & $\begin{array}{c}24,2 \\
M\end{array}$ & $\begin{array}{c}26,6 \\
M\end{array}$ & $\begin{array}{c}25,6 \\
M\end{array}$ \\
\hline $\begin{array}{l}\text { Financial compo- } \\
\text { nent }\end{array}$ & $\begin{array}{c}25,9 \\
\mathrm{M}\end{array}$ & $\begin{array}{c}23,9 \\
\mathrm{M}\end{array}$ & $\begin{array}{c}28,2 \\
M\end{array}$ & $\begin{array}{c}27,1 \\
M\end{array}$ & $\begin{array}{c}26,4 \\
\mathrm{M}\end{array}$ & $\begin{array}{c}23,8 \\
\mathrm{M}\end{array}$ & $\begin{array}{c}24,1 \\
\mathrm{M}\end{array}$ \\
\hline & $\begin{array}{c}7,9 \\
\mathrm{~L}\end{array}$ & $\begin{array}{c}9,7 \\
\mathrm{~L}\end{array}$ & $\begin{array}{l}4,6 \\
\mathrm{~L}\end{array}$ & $\begin{array}{c}6,7 \\
\mathrm{~L}\end{array}$ & $\begin{array}{c}9,1 \\
\mathrm{~L}\end{array}$ & $\begin{array}{c}11,3 \\
\mathrm{~L}\end{array}$ & $\begin{array}{c}7,3 \\
\mathrm{~L}\end{array}$ \\
\hline $\begin{array}{l}\text { Organizational and } \\
\text { management com- } \\
\text { ponent }\end{array}$ & $\begin{array}{l}78 \\
\mathrm{M}\end{array}$ & $\begin{array}{l}82 \\
\mathrm{H}\end{array}$ & $\begin{array}{l}79 \\
M\end{array}$ & $\begin{array}{l}80 \\
\mathrm{H}\end{array}$ & $\begin{array}{l}77 \\
\mathrm{M}\end{array}$ & $\begin{array}{c}84 \\
\mathrm{H}\end{array}$ & $\begin{array}{c}82 \\
\mathrm{H}\end{array}$ \\
\hline $\begin{array}{l}\text { Innovative compo- } \\
\text { nent }\end{array}$ & $\begin{array}{c}26,8 \\
\mathrm{~L}\end{array}$ & $\begin{array}{c}25,9 \\
\text { L }\end{array}$ & $\begin{array}{c}25,6 \\
\mathrm{~L}\end{array}$ & $\begin{array}{c}25,4 \\
\mathrm{~L}\end{array}$ & $\begin{array}{c}25,3 \\
\mathrm{~L}\end{array}$ & $\begin{array}{c}26,1 \\
\mathrm{~L}\end{array}$ & $\begin{array}{c}25,9 \\
\text { L }\end{array}$ \\
\hline
\end{tabular}


The approach suggested for a systematic evaluation of a hotel enterprise's innovative potential helps its management to evaluate the nature of changes in the degree of innovative potential or its individual structural components compared to previous periods and to respond quickly to changes.

Therefore, based on the current level of innovative potential, hotel management will, on the one hand, agree on the course of creation of the desired innovative approach and, on the other, assess the innovative opportunities that the hotel has. This means that a creative approach that suits a hotel company's requirements and ensures its successful innovative growth can be justified and executed on the basis of a thorough and objective assessment of innovative potential.

Conclusions. Practical use of the proposed innovative potential evaluation approach has shown that the hotels we are evaluating have an unsatisfactory state of innovative potential, i.e. poor innovative potential. It is therefore necessary to take concrete action to change these enterprises' growth strategies.

Studies show that cognitive, organizational and administrative are the main components of their creative capacity. There are prospects for future development in the creative direction. Their technological ability is a steady propensity to increase it, both at an average and high level, suggesting the existence of growth resources and a rise in their use in the future. Such hotel management will retain such components at the appropriate level, making full use of their development opportunities.

The manufacturing, technological, financial and marketing components of the hotels ' creative capacity are currently at a low level, but they have both strengths and weaknesses. These should be paid close attention to the management of hotel companies in order to build possible advantages over time, progressing to a higher quality standard. The weakness of the manufacturing and technological element is reflected by a rather high rate of deterioration of equipment in all the under study hotel enterprises, lack of modernization and introduction of advanced equipment in the reporting year.

Depreciation of manufacturing resources is one of the main reasons why corporations creative processes their reactivity - are significant. The prevailing introduction of innovative products based on satisfying the current demand for services markets is capable of providing short-term financial revenue, but does not provide strategic advantages for businesses. If the equipment of the companies studied continues to age. That's it. It will soon be very difficult to change the content and technological basis, upgrade fixed assets and deliver profitable innovative products. The analysis of the financial element revealed that the hotels are financially dependent, only about $70 \%$ of the share of their resources is covered by their own capital, and the fund's turnover ratios are characterized by an insufficiently high level of their business activity.

To ensure the company's productive growth, it is necessary to ensure that the financial resources of hotel businesses are used effectively, to incorporate robust processes for attracting financial flows, and to create a framework for a coherent diagnosis of project execution within the hotel.

With regard to the advertising aspect, hotels have poorly developed market research, which involves a series of measures to promote hotel services.

Finally, the study element remains the weakest among the components of the studied hotels' creative capacity. The data show that all of this component's quantitative variables are equal to zero. Their management needs to adjust their policies as soon as possible, reorienting them not only in the short and medium term to achieve the desired results, but also laying the foundation for long-term success. And it will be difficult to achieve these successes without the availability of intellectual property and access to it, licensing agreements, partnership with research organizations.

Solving existing problems in a number of components of businesses ' innovative potential requires designing and enforcing a series of steps to improve the use and growth of their innovative potential structural components.

Trying to match the asset composition and boost its proportions, the organization improves its efficiency, will affect the size of innovative potential, thus improving strategic management of innovative activities, ensuring successful execution of selected innovative strategies.

\section{Literature}

1. Алиев Т., Бабаев Л. Инвестиционно-инновационное обеспечение развития экономики Азербайджана. Наука и инновации. 2012. №9 (115). 2. Алиева Ш., Касумова Е. Инновационное развитие экономики Азербайджанской Республики и управление инновационной деятельностью предприятий. Journal of Economy and Business. 2017. Vol.4, part 1. 3. Гусейнова Э. Анализ и оценка конкурирующих данных потенциала туристических ресурсов Азербайджанской Республики. Проблемы формирования модели национального развития. Баку, 2010. 4. Гончаров А.А. Анализ инновационного потенциала Ульяновской области. Инновационная деятельность. 2011. №48 (255). 5. Джабиев Р. Отраслевые и региональные диспропорции в инновационной сфере промышленности Азербайджана. Общество и экономика. 2014. № 9. 6. Дорофеев В.Д., Дресвянников В.А. Инновационный менеджмент: Учеб. пособие Пенза: Изд-во Пенз. гос. ун-та, 2003. 189 с. 7. Имайкина О.И. Стратегическое управление инновационной деятельностью промышленных предприятий: автореф. дисс. на соискание ученой степени канд. экон. наук. Саранск, 2014. 8. Макарова Д.Д., Магжанова Л.П., Марутько С.С. Инновационные услуги в 
гостиничном бизнесе как инструмент повышения конкурентоспособности. URL: https:/cyberleninka.ru/ article/ n/innovatsionnye-uslugi-v-gostinichnom-biznesekak-instrument-povysheniya-konkurentosposobnosti.

9. Фатхутдинов Р.А. Инновационный менеджмент: учебник для вузов. 6-е изд. СПб.: Питер, 2008. 448 с. 10. URL: https://www.booking.com/country/az.ru.html.

\section{References}

1. Aliyev T., Babayev L. (2012). Investment and innovation support of Azerbaijan economy development. Science and Innovation Journal, No. 9 (115) [in Russian].

2. Aliyeva Sh., Kasumova E. (2017). Innovative development of the economy of the Republic of Azerbaijan and management of innovation activity of enterprises. Journal of Economy and Business, vol.4, part 1 [in Russian].

3. Guseynova E. (2010). Analysis and evaluation of competing data of tourism resources potential of the Republic of Azerbaijan. Challenges in shaping the national development model. Baku [in Russian].

4. Goncharov A.A. (2011). Analysis of innovative potential of Ulyanovsk region. Innovation, № 48 (255) [in Russian].

5. Jabiev R. (2014). Otrasly and regional imbalances in the innovative sphere of Azerbaijan 's industry. Society and Economics, No. 9 [in Russian].

6. Dorofeev V.D., Dresvyannikov V.A. (2003). Innovation Management: Training Manual. Penza, Penza State University, 189 p. [in Russian].

7. Imaykina O. I. (2014). Strategic management of industrial innovation. Extended abstract of candidate's thesis. Saransk [in Russian].

8. Makarov D.D., Magzhanova L.P., Marutko S.S. Innovative services in the hotel business as a tool to increase competitiveness. Retrieved from https://cyberleninka.ru/ article/n/innovatsionnye-uslugi-v-gostinichnom-biznesekak-instrument-povysheniya-konkurentosposobnosti [in Russian].

9. Fathutdinov R.A. (2008). Innovation management: textbook for universities. 6th ed. SPb., Peter. 448 p. [in Russian].

10. Retrieved from https://www.booking.com/country/az.ru.html.

Рза-заде Нурай Рауф к. Дослідження економічного потенціалу інноваційного розвитку готельних підприсмств Азербайджану

Впровадження інноваційних технологій - істотно важливий і необхідний чинник підвищення конкурентоспроможності компаній. Процеси глобалізації, виникнення нових потреб ринку і можливостей їх задоволення змушує переходити на шлях інноваційного розвитку і готельні підприємства.

Метою даного дослідження $є$ комплексний розгляд економічного потенціалу інноваційного розвитку готельних підприємств Азербайджану, для визначення перспективних напрямків розвитку даних підприємств і вибору оптимальних інноваційних стратегій, що від- повідають можливостям даних готельних підприємств, що забезпечують їх успішний інноваційний розвиток.

Відповідно до поставленої мети, у статті розглянуто структурні компоненти інноваційного потенціалу готелів, дана система узагальнюючих показників оцінки інноваційного потенціалу готелів м. Баку, а саме таких їі складових, як: інтелектуальна, наукова, науководослідницька, виробничо-технічна, фінансова, маркетингова і організаційно-управлінська; запропонована авторська методика комплексної оцінки інноваційного потенціалу готельних підприємств, заснована на використанні системи якісних і кількісних показників, що характеризують, як стан його окремих структурних компонентів, так і загальний інтеграційний рівень інноваційного потенціалу готельних підприємств.

При написанні статті використовувалися методи емпіричного дослідження: порівняння, спостереження, угрупувань і такі загальнологічні методи, як логічне узагальнення, статистичний аналіз і системний підхід.

Застосування економіко-математичних і економіко-статистичних методів дозволило дати об'єктивну кількісну оцінку інноваційного потенціалу готелів, визначити тенденції розвитку його структурних компонентів, виявити існуючі в них диспропорції і протиріччя, прогнозувати їх подальший розвиток.

Результатом дослідження $є$ виявлення існуючих проблем у ряді складових інноваційних потенціалів готельних підприємств м. Баку, а також розробка комплексу заходів щодо активізації використання економічного потенціалу інноваційного розвитку аналізованих готелів.

Ключові слова: готельні підприємства, інноваційний розвиток, оцінка інноваційного потенціалу, конкурентоспроможність готельних підприємств.

Rza-zadeh Nuray Rauf. Study of the Economic Potential of the Innovative Development of Hotel EnterPrises in Azerbaijan

Innovation implementation is a very important and necessary element in improving company competitiveness. Globalization processes, the emergence of new market demands and opportunities to meet these needs force hotel companies to move on to the path of creative growth.

Our study aims at a comprehensive review of the economic potential of Azerbaijan's creative hotel business growth. This is necessary to identify promising areas and select the best creative approaches for the growth of these enterprises. Those approaches will suit those hotel companies ' capabilities.

In line with this aim, the article discusses the structural components of hotels ' innovative potential, including a framework for evaluating hotels in Baku's innovative potential. We are talking about the element intellectual, science, academic, manufacturing and technological, economic, marketing, organizational and managerial. Moreover, the researchers suggested a framework for a systematic analysis of hotel businesses ' creative capacity. It is focused on the use of a system of qualitative and quantitative measures that describe both the state of its individual struc- 
tural components and the overall level of integration of hotel enterprises ' creative potential.

Empirical research approaches-comparison, evaluation, grouping, as well as logical generalization, statistical analysis, and a systematic approach - were used when writing the article.

The application of economic-mathematical and economic-statistical methods allowed an unbiased quantitative analysis of hotels' creative potential, identified patterns in the growth of their structural components, identified imbalances and contradictions, and predicted their further development.

The study succeeds in finding existing problems in some of the constituent elements of hotel businesses' creative capacity in Baku. The outcome is also a series of steps to aggressively harness the economic potential of hotels' creative growth.

Keywords: hotel businesses, innovative growth, innovative potential evaluation, competitiveness of hotel businesses.

Рза-заде Нурай Рауф. Исследование экономического потенциала инновационного развития гостиничных предприятий Азербайджана

Внедрение инноваций - существенно важный и необходимый фактор повышения конкурентоспособности компаний. Процессы глобализации, возникновение новых потребностей рынка и возможностей их удовлетворения заставляет переходить на путь инновационного развития и гостиничные предприятия.

Целью данного исследования является комплексное рассмотрение экономического потенциала инновационного развития гостиничных предприятий Азербайджана, для определения перспективных направлений развития данных предприятий и выбора оптимальных инновационных стратегий, соответствующих возможностям данных гостиничных предприятий, обеспечивающих их успешное инновационное развитие.
В соответствии с поставленной целью, в статье рассмотрены структурные компоненты инновационного потенциала гостиниц, дана система обобщающих показателей оценки инновационного потенциала отелей г. Баку, а именно таких ее составляющих, как: интеллектуальная, научная, научно-исследовательская, производственно-техническая, финансовая, маркетинговая и организационно-управленческая; предложена авторская методика комплексной оценки инновационного потенциала гостиничных предприятий, основанная на использовании системы качественных и количественных показателей, характеризующих, как состояние его отдельных структурных компонентов, так и общий интеграционный уровень инновационного потенциала гостиничных предприятий.

При написании статьи использовались методы эмпирического исследования: сравнения, наблюдения, группировок и такие общелогические методы, как логическое обобщение, статистический анализ и системный подход.

Применение экономико-математических и экономико-статистических методов позволило дать объективную количественную оценку инновационному потенциалу гостиниц, определить тенденции развития его структурных компонентов, выявить существующие в них диспропорции и противоречия, прогнозировать их дальнейшее развитие.

Результатом исследования является выявление существующих проблем в ряде составляющих инновационных потенциалов гостиничных предприятий г. Баку, а также разработка комплекса мероприятий по активизации использования экономического потенциала инновационного развития анализируемых гостиниц.

Ключевые слова: гостиничные предприятия, инновационное развитие, оценка инновационного потенциала, конкурентоспособность гостиничных предприятий.

Received by the editors: 26.11 .2019 and final form 19.12.2019 